\title{
Antibacterial Effect of Heather Honey (Calluna vulgaris) against Different Microorganisms of Clinical Importance
}

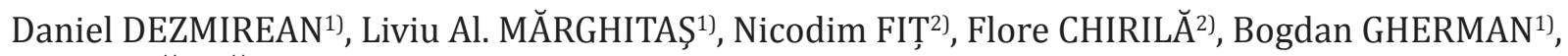 \\ Rodica MĂRGĂOAN ${ }^{1)}$, Adriana AURORI ${ }^{1)}$ and Otilia BOBIŞ ${ }^{1 * j}$ \\ ${ }^{1}$ Department of Apiculture and Sericulture, University of Agricultural Sciences and Veterinary Medicine \\ Cluj-Napoca, Romania \\ ${ }^{2}$ Department of Microbiology (Veterinary Medicine), University of Agricultural Sciences and Veterinary \\ Medicine Cluj-Napoca, Romania. \\ *Corresponding author, email: obobis@usamvcluj.ro
}

Bulletin UASVM Animal Science and Biotechnologies 72(1) / 2015

Print ISSN 1843-5262; Electronic ISSN 1843-536X

DOI:10.15835/buasvmcn-asb:10562

\begin{abstract}
Heather (Calluna vulgaris) honey is a special type of honey, highly valued for its characteristic strong taste, unusual texture and health properties. Antibacterial activity of honey is due to low acidity, high osmolarity, content of hydrogen peroxide and other components such as polyphenolic compounds. In this paper we proposed evaluation of the in vitro antibacterial effect of heather honey on some clinically important bacterial species. Heather honey collected from Cluj Region was chemically characterized and then subjected to antimicrobial activity determination. Disc diffusion method and dilution susceptibility test for antibacterial activity on different Gram positive and Gram negative bacteria were used. As heather honey is tixotrophic, different solutions in ultrapure water were made and it was found that $80 \%$ dilution was suitable for the experiment. The diameters of inhibition obtained were between 9-12 $\mathrm{mm}$ at bacterial strains tested. Heather honey has a high antibacterial activity, comparable to honey types that are used worldwide in the treatment of different bacterial infections. Further detailed studies must be carried out to establish the rightful status of this valuable type of honey.
\end{abstract}

Keywords: antibacterial activity, bacteria, honey, human pathogens

\section{INTRODUCTION}

Honey has been used since ancient times as sweetener or in traditional medicine, even though the explanations for its properties came much later. Today modern science has made it possible to explain almost all medical properties of different types of honey, such as: antioxidant (Estevinho et al., 2008; Mărghitaș et al., 2009), antibacterial (Molan, 1992; Weston, 2000; Oelschlaegel et al., 2012), antifungal (Irish et al., 2006; Estevinho et al., 2012), antiviral (Molan, 2001a) and useful for treating various wounds or burns (Molan 2001b; Haynes, 2011).
The antibacterial activity of honey is due to its acidity (low pH), osmotic effect, high sugar concentration, presence of bacteriostatic and bactericidal factors (hydrogen peroxide, antioxidants, lysozyme, polyphenols, phenolic acids, flavonoids, methylglyoxal, and bee peptides) (Brudzynski et al., 2011; Bobiş et al., 2013; Izraili 2014).

As bees use nectar from different flowers and also sweet secretions as raw material to produce honey, the final product will have different compositions and physicochemical properties (different osmolarity, sugar composition, acidity, 
bioactive compounds). For this reason, the antimicrobial properties of different types of honey can vary over 100 -fold (Lusby et al., 2005).

Heather (Calluna vulgaris) honeys possess a particular characteristic called tixothropy, due to the presence of a specific colloidal protein. For this type of honey, water content is accepted to be more than $20 \%$, for electrical conductivity often over $0.8 \mathrm{mS} / \mathrm{cm}$ (Dezmirean et al., 2010; Moise et al., 2013). It is a dark colour honey, with medium to strong aroma and odour, and a particular gel consistency (Persano Oddo and Piro, 2004).

Heather honey is used in the therapy of different inflammation of the respiratory tract and oral cavity, and is also recommended in the treatment of urinary infections or prostate diseases (Feás et al., 2013). It is known to have a high antibacterial activity, comparable to or even higher than Manuka honey or other well known antibacterial types of honey (Deb Mandal and Mandal, 2011; Alnaimat et al., 2012; Bobiş et al., 2013).

While current studies focus increasingly on the chemical composition of heather honey: palynological and physicochemical composition (Andrade et al., 1999; Pires et al., 2009; Dezmirean et al., 2010; Moise et al., 2013), possible floral marker evaluation (Oelschlägel, 2011), antioxidant properties (Estevinho et al., 2012; Moise et al., 2013), few focused on the antimicrobial or antifungal properties of these types of honey (Henriques et al., 2005; Feás and Estevinho, 2011).

Consequently, the aim of the present study was to characterize different samples of Romanian heather honey and to assess the "in vitro" antimicrobial properties of heather honey against some clinically important bacterial species, including Staphylococcus aureus, Bacillus cereus, Escherichia coli, Pseudomonas aeruginosa, Salmonella enteritidis and Salmonella typhi. Moreover, different correlations among phenolics, flavonoids and other chemical parameters and antimicrobial properties of honeys were studied.

\section{MATERIALS AND METHODS}

Honey samples. For the experiment, six samples of heather honey collected from Cluj County (2012 - 2013) were used to determine the chemical composition and antibacterial properties. Samples were stored in a dark place at $22 \pm 1^{\circ} \mathrm{C}$ temperature; all determinations took place no more than six months from the harvest date.

Botanical identification. All honeys were declared as heather monofloral honeys by beekeepers, but in the lab they were subjected to qualitative pollen analysis, using Louvreaux et al. (1978) method without acetolysis, to confirm the declared botanical origin.

Bioactive compounds determination. Total phenolic content and total flavonoid content were determined for all honey samples, following known laboratory methods (Ferreira et al., 2009). For total phenolic content, the Folin Ciocâlteu method (Singleton et al., 1999) with some adjustments was used, expressing the results as mgGA equivalents per $100 \mathrm{~g}$ honey, using a calibration curve made with different concentrations of Gallic acid ( $\left.y=8.03727 \mathrm{x}-0.06356, \mathrm{r}^{2}=0.9996\right)$. For total flavonoid content, the aluminium chloride method was used (Kim et al., 2003), with $\mathrm{NaNO}_{2}$ and $\mathrm{NaOH}$ solutions added as reagents. For the calibration curve, different concentrations of quercetin were used, and the results were expressed as mg QE equivalents per $100 \mathrm{~g}$ honey $\left(y=11.11546 x-0.00664, r^{2}=0.9989\right)$.

Antioxidant potential. Knowing that heather honey has antioxidant properties due to its chemical composition, two different methods were used to assess the antioxidant activity. DPPH (Blasa et al., 2006) and FRAP (Benzie and Strain, 1996) methods were used in the experiment and the antioxidant activity was expressed as radical scavenging activity against the DPPH radical and total antioxidant power expressed as FRAP value.

Antimicrobial activity tests. Six reference bacterial strains were used in this experiment: Staphylococcus aureus - ATCC 6538P; Bacillus cereus - ATCC 14579; Escherichia coli ATCC 10536; Pseudomonas aeruginosa - ATCC 27853; Salmonella enteritidis ATCC - 13076; Salmonella typhi - ATCC - 14028.

Bacterial strains from collection are seeded in liquid medium (nutrient broth), incubated at $37^{\circ} \mathrm{C}$ for 24 hours. First, the antibacterial activity was tested by disc diffusion method adapted for honey. Sterile Petri dishes of $9 \mathrm{~cm}$ diameter in sterility conditions were used and $24 \mathrm{~mL}$ Mueller-Hinton agar was poured inside, to obtain a layer of $5 \mathrm{~mm}$ thickness.

Plates were maintained 10-15 min with the lid open for medium solidification. 
After well cutting, the plate was flooded with a bacterial suspension for 18-20 hours with a density of 0.5 McFarland. Excess of bacterial suspension was removed and let to dry. Every well was then treated with $20 \mu \mathrm{l}$ honey solution (80\%), and plates were incubated at $37^{\circ} \mathrm{C}$ for 24 hours.

If the used germ was sensitive to the honey solution, a circular aria of variable size was observed around the well, where the bacteria did not grow any more.

The second procedure was dilution susceptibility test, where we determined the minimum inhibitory concentration determination (MIC). The measurements used clear 96-U-shaped Well Plates, of capacity of $200 \mu \mathrm{l}$ each, sterile MuellerHinton broth, and bacterial cultures in liquid medium. Using multichannel automatic pipette, $100 \mu \mathrm{l}$ Mueller-Hinton broth is placed in the first 10 wells of the plate and in the $12^{\text {th }}$ of every row. In the first well of each row, $100 \mu$ of honey solution was added and the mixture was aspired repeatedly from the well. Then, $100 \mu \mathrm{l}$ from the first well is aspired and placed in the second well, homogenizing again. This procedure is done until the $10^{\text {th }}$ well is reached, from which $100 \mu \mathrm{l}$ is discharged.

Finally, every well is seeded with $10 \mu \mathrm{l}$ of 24hour bacterial culture, including the $12^{\text {th }}$ well, which will serve as control for the bacterial strain. The plate is covered with a lid and incubated at $37^{\circ} \mathrm{C}$ for 24 hours.

The minimum inhibitory concentration (MIC) is given by the smallest dilution from the analysed product (last well) in which the bacterial culture is inhibited (broth remains clear).

\section{RESULTS AND DISCUSSION}

In order to verify the botanical origin of honey samples, palynological analyses were carried out, following the Louvreaux et al. (1978) method. The sediment obtained from $10 \mathrm{~g}$ honey solution in $5 \% \mathrm{H}_{2} \mathrm{SO}_{4}$, stained and fixed on a microscopic slide, showed a mean of $34.2 \%$ heather pollen (Fig.1) for all samples, other present species being black locust (Robinia pseudoacacia), chestnut (Aesculus hippocastanum), rape (Brassica sp.) and meadowsweet (Filipendula ulmaria). These other pollens were lower than $5 \%$ for each species, so honey samples were classified as monofloral heather honeys.

For the measurement of antioxidant activity of honey samples by means of DPPH method, $10 \%$ honey solutions in ultrapure water were made. DPPH radical was dissolved in methanol in order to obtain a $2.4 \mathrm{mM}$ solution. As positive control, 6-hydroxy-2,5,7,8-tetramethylcroman2-carboxilic acid (Trolox) in methanol was used. A calibration curve of Inhibition \% versus Trolox concentration was made, using six Trolox concentrations (Fig.2A).

For total antioxidant power, the measurements were made using freshly prepared FRAP reagent. The absorbance of reagents and standard solutions were read at 0 and $15 \mathrm{~min}$ at $593 \mathrm{~nm}$. Results were expressed as FRAP values ( $\mu \mathrm{M} \mathrm{Fe}^{2+} / \mathrm{g}$ sample). The calibration curve was made using eight dilutions of $\mathrm{FeSO}_{4}$ (stock solution of 1mM/L)(Fig.2B).

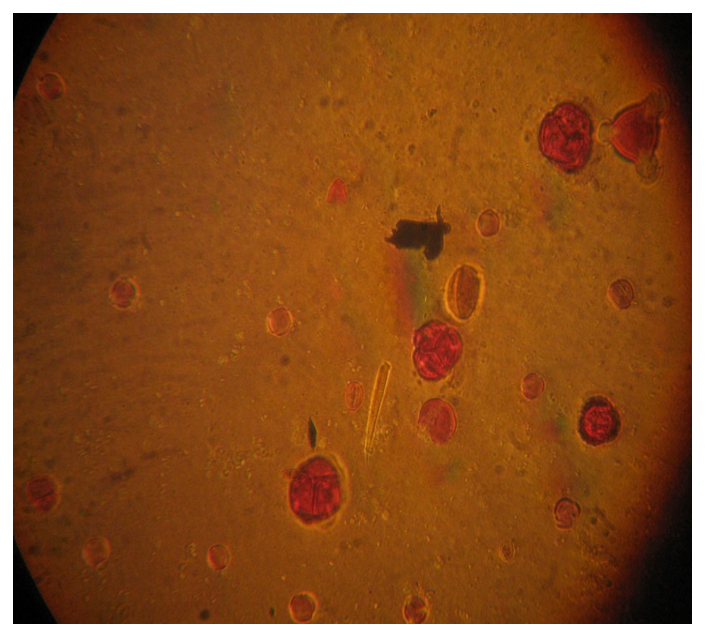

Fig.1. Specific pollen of heather (Calluna vulgaris), obtained from the sediment of heather honey: optic microscopy (400X magnification) 


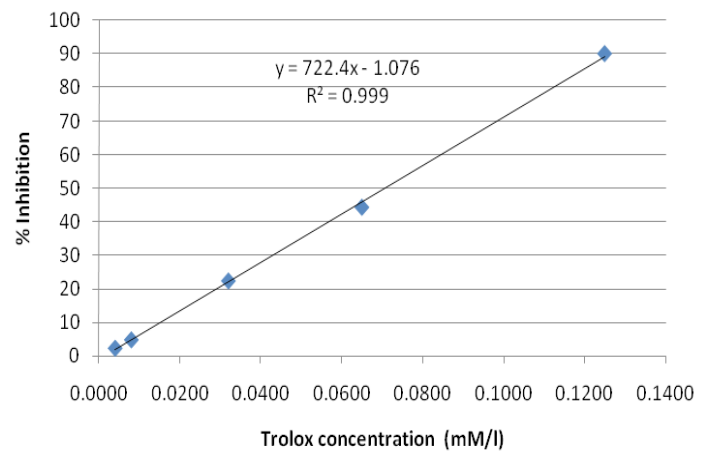

A

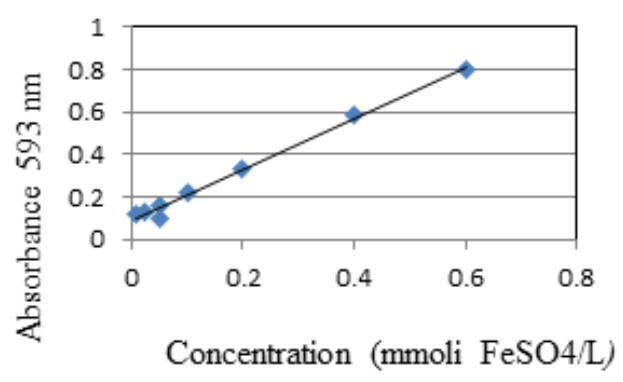

$\mathrm{y}=1,2005 \mathrm{x}+0,0911$

$$
\mathrm{R}^{2}=0,992
$$

Fig.2. Calibration curve Inhibition \% versus Trolox concentrations for radical scavenging activity determination (A); Calibration curve of absorbance versus concentration for $\mathrm{FeSO}_{4}$, for total antioxidant power measurement (B)

Honey samples were analysed in the same way as standards and using the equation curve $(y=722.4 x-1.076)$, the antioxidant activity of honey was expressed as mM Trolox/kg honey (Tab, 1).

In the present study, the concentration of total phenolic content ranged between 59.7 and $72.1 \mathrm{mgGAE} / 100 \mathrm{~g}$ honey, with a mean value of $62.7 \mathrm{mgGAE} / 100 \mathrm{~g}$ honey (Table 1). These results were in accordance with existing literature data (Andrade et al. 1999; Estevinho et al., 2012; Feás et al., 2013; Moise et al., 2013).

Total flavonoid content from the analyzed samples was lower than total polyphenols, as flavonoids are a part of these bioactive compounds (Tab. 1).

Higher amounts of bioactive compounds exhibit also high antioxidant properties. It is known that darker honeys possess high amounts of polyphenols, and consequently high antioxidant properties (Estevinho et al., 2008; Ferreira et al., 2009).

The antimicrobial activity of the honey samples was tested against the most common pathogens that cause different infections. Generally, these microorganisms may have developed resistance to different drugs, because of the random use of antibiotics. The need for finding new alternatives to treat these bacteria led us to testing different types of honey, heather honey included.

Tested Gram positive (Bacillus cereus and Staphylococcus aureus) and Gram negative (Escherichia coli, Salmonella enteritidis, Salmonella typhi and Pseudomonas aeruginosa) bacteria presented different susceptibility towards heather honey solution. Table 2 presents both inhibition zone diameter and minimum inhibitory concentration of heather honey and bacterial strains.

Tab. 1. Bioactive compounds and antioxidant activity of heather honey

\begin{tabular}{ccccc}
\hline $\begin{array}{c}\text { Honey } \\
\text { sample }\end{array}$ & $\begin{array}{c}\text { Total polyphenols* } \\
\text { (mgGAE/100g } \\
\text { honey) }\end{array}$ & $\begin{array}{c}\text { Total } \backslash \text { flavonoids* } \\
\text { (mgQE/100 g } \\
\text { honey) }\end{array}$ & $\begin{array}{c}\text { Radical scavenging } \\
\text { activity* (mmol } \\
\text { Trolox/g) }\end{array}$ & $\begin{array}{c}\text { Total antioxidant } \\
\text { power* }(\mu \text { mol } \\
\text { Fe2+/g) }\end{array}$ \\
\hline Heather 1 & $59.74 \pm 2.45$ & $29.54 \pm 4.35$ & $4.86 \pm 1.21$ & $10.25 \pm 2.12$ \\
\hline Heather 2 & $61.25 \pm 6.21$ & $31.24 \pm 2.54$ & $4.98 \pm 0.52$ & $11.32 \pm 2.20$ \\
\hline Heather 3 & $57.24 \pm 2.54$ & $29.45 \pm 6.21$ & $3.66 \pm 1.54$ & $9.98 \pm 1.56$ \\
\hline Heather 4 & $72.13 \pm 6.51$ & $36.21 \pm 2.64$ & $4.34 \pm 0.62$ & $12.42 \pm 1.85$ \\
\hline Heather 5 & $66.45 \pm 7.21$ & $31.48 \pm 4.52$ & $4.56 \pm 1.24$ & $11.32 \pm 2.41$ \\
\hline Heather 6 & $59.46 \pm 5.22$ & $34.28 \pm 3.45$ & $3.98 \pm 0.68$ & $10.24 \pm 2.53$ \\
\hline Mean & $\mathbf{6 2 . 7 1}$ & $\mathbf{3 2 . 0 3}$ & $\mathbf{4 . 3 9}$ & $\mathbf{1 0 . 9 2}$ \\
*Values represent the mean of three independent determinations \pm standard deviation &
\end{tabular}


Tab. 2. Inhibition diameter zone/minimum inhibitory concentration of heather honey against different bacterial strains

\begin{tabular}{ccccccc}
\hline $\begin{array}{c}\text { Honey } \\
\text { sample }\end{array}$ & $\begin{array}{c}\text { Staphylococcus } \\
\text { aureus ATCC } \\
\text { 6538P }\end{array}$ & $\begin{array}{c}\text { Bacillus } \\
\text { cereus ATCC } \\
14579\end{array}$ & $\begin{array}{c}\text { Escherichia } \\
\text { coli ATCC } \\
10536\end{array}$ & $\begin{array}{c}\text { Pseudomonas } \\
\text { aeruginosa } \\
\text { ATCC } 27853\end{array}$ & $\begin{array}{c}\text { Salmonella } \\
\text { enteritidis } \\
\text { ATCC } 13076\end{array}$ & $\begin{array}{c}\text { Salmonella } \\
\text { typhi } \\
\text { ATCC-14028 }\end{array}$ \\
\hline Heather 1 & $10 \mathrm{~mm} / 4.2 \%$ & $9 \mathrm{~mm} / 2.6 \%$ & $11 \mathrm{~mm} / 6.8 \%$ & $10 \mathrm{~mm} / 8.4 \%$ & $10 \mathrm{~mm} / 2.4 \%$ & $9 \mathrm{~mm} / 7.8 \%$ \\
\hline Heather 2 & $10 \mathrm{~mm} / 5.0 \%$ & $11 \mathrm{~mm} / 1.6 \%$ & $10 \mathrm{~mm} / 7.2 \%$ & $10 \mathrm{~mm} / 8.0 \%$ & $12 \mathrm{~mm} / 2.6 \%$ & $10 \mathrm{~mm} / 6.8 \%$ \\
\hline Heather 3 & $9 \mathrm{~mm} / 6.4 \%$ & $10 \mathrm{~mm} / 1.8 \%$ & $11 \mathrm{~mm} / 7.4 \%$ & $12 \mathrm{~mm} / 6.6 \%$ & $12 \mathrm{~mm} / 2.8 \%$ & $9 \mathrm{~mm} / 8.4 \%$ \\
\hline Heather 4 & $10 \mathrm{~mm} / 4.6 \%$ & $9 \mathrm{~mm} / 2.2 \%$ & $10 \mathrm{~mm} / 6.8 \%$ & $11 \mathrm{~mm} / 6.2 \%$ & $10 \mathrm{~mm} / 3.0 \%$ & $9 \mathrm{~mm} / 8.2 \%$ \\
\hline Heather 5 & $11 \mathrm{~mm} / 5.2 \%$ & $10 \mathrm{~mm} / 2.0 \%$ & $9 \mathrm{~mm} / 7.4 \%$ & $11 \mathrm{~mm} / 6.4 \%$ & $12 \mathrm{~mm} / 2.6 \%$ & $10 \mathrm{~mm} / 6.6 \%$ \\
\hline Heather 6 & $10 \mathrm{~mm} / 6.2 \%$ & $9 \mathrm{~mm} / 2.4 \%$ & $9 \mathrm{~mm} / 7.6 \%$ & $12 \mathrm{~mm} / 5.2 \%$ & $12 \mathrm{~mm} / 2.2 \%$ & $9 \mathrm{~mm} / 6.8 \%$ \\
\hline Mean & $\mathbf{1 0 m m} / \mathbf{5 . 3} \%$ & $\mathbf{9 . 6 m m} / \mathbf{2 . 1 \%}$ & $\mathbf{1 0 m m} / \mathbf{7 . 2} \%$ & $\mathbf{1 1 m m} / \mathbf{6 . 8} \%$ & $\mathbf{1 1 . 3 m m} / \mathbf{2 . 6 \%}$ & $\mathbf{9 . 3 m m} / \mathbf{7 . 4 \%}$ \\
\hline
\end{tabular}

The information available in the literature regarding the antimicrobial activity of honey is sometimes controversial and differs from one type of honey to another. Table 2 present the results obtained for Romanian heather honey as inhibition diameter and MIC, considering different Gram positive and Gram-negative bacteria. Differences among bacteria were observed, although not statistically significant. P. aeruginosa and $S$. enteritidis have the highest inhibition diameter (11 and $11.3 \mathrm{~mm}$, respectively), while $S$. typhi and B. cereus have the smallest diameter $(9.3$ and $9.6 \mathrm{~mm}$ ). MIC ranged between 2.1 and $7.4 \%$ honey solution, B.cereus being the most sensitive to the honey effect and (2.1\%), $S$. typhi being the most resistant.

Comparable results were obtained for Portuguese heather honey (Feás et al. 2011; Estevinho et al., 2012; Feás et al. 2013).

\section{CONCLUSION}

The general observation regarding the antibacterial activity of heather honey against different Gram negative and Gram-positive bacteria was that the tested microorganisms were sensitive to this type of honey. High inhibition zone diameter in disc diffusion method and small concentration of honey for determination of minimum inhibitory concentration put this Romanian honey among the first honeys in the world regarding antimicrobial activity.

The study demonstrates that alternative medicine has now gained scientific support in explaining the mechanisms of action and the compounds that are responsible for biological properties of bee products, in our case honey.

Acknowledgments. This research was partly supported by POS CCE project RoBeeTech, no. 206/2010 and through the Partnerships in Priority Areas Programme - PN II, developed with the support of MEN - UEFISCDI, project no. 148/2014.

\section{REFERENCES}

1. Alnaimat S, Wainwright M, Al'Abri K (2012). Antibacterial potential of honey from different origins: a comparison with manuka honey. J Microbiol Biotechnol Food Sci 1(5):1328-1338.

2. Andrade PB, Amaral MT, Isabel P, Carvalho J, Seabra R, Cunha A (1999). Physicochemical attributes and pollen spectrum of Portuguese heather honeys. Food Chem 66:503-510.

3. Benzie IFF, Strain JJ (1996). The ferric reducing ability of plasma (FRAP) as a measure of "antioxidant power": The FRAP assay. Anal Biochem 239:70-76.

4. Blasa M, Candiracci M, Accorsi A, Piacentini PM, Albertini MC, Piatti E (2006). Raw millefiori honey is packed full of antioxidants. Food Chem 97:217-222.

5. Bobiş O, Mărghitaș LA, Dezmirean D, Gherman B, Chirilă F (2013). In vitro antibacterial activity of unifloral honeys against honeybee pathogens Paenibacillus larvae and Escherichia coli. Lucrări Stiințifice - Seria Zootehnie 55(160).

6. Brudzynski C, Abunaker A, St-Martin L, Castle A (2011), Re-examining the role of hydrogen peroxide in bacteriostatic and bactericidal activities of honey. Front Microbiol 2:213.

7. Deb Mandal M, Mandal S (2011). Honey: its medicinal property and antibacterial activity. Asian Pacific J Tropical Biomed 1(2)154-160.

8. Dezmirean D, Mărghitas LA, Bobis O, Stan L, Bonta V, Maghear O, Dinita G, Morar O (2010). Physical-Chemical 
Attributes and Mineral Content of Heather Honey (Calluna vulgaris). Bulletin UASVM Animal Science and Biotechnologies, 67(1-2): 163-168.

9. Estevinho LM, Pereira AP, Moreira L, Dias LG, Pereira E (2008). Antioxidant and antimicrobial effects of phenolic compounds extracts of Northeast Portugal honey. Food Chem Toxicol 46:3774-3779.

10. Estevinho LM, Afonso SE, Feás Z (2011). Antifungal effect of lavender honey against Candida albicans, Candida krusei and Cryptococcus neoformans. J Food Sci Technol 48:640-643.

11. Estevinho LM, Feás X, Seijas JA, Vazquez-Tato MP (2012). Organic honey from Tras-Os-Montes región (Portugal): Chemical, palynological, microbiological and bioactive compounds characterization. Food Chem Toxicol 50:258264.

12. Feás X, Estevinho LM (2011). A survey of the in vitro antifungal activity of heather (Erica sp.) organic honey. J Med Food 14:1-5.

13. Ferreira ICFR, Aires E, Barreira JCM, Estevinho ML (2009). Antioxidant activity of Portuguese honey samples: different contributions to the entire honey and phenolic extract. Food Chem 114:1438-1443.

14. Haynes JS (2011). Achieving clinical ourcomes: the use of honey. Wound Essentials 6:14-19.

15. Henriques A, Burton NF, Cooper RA (2005). Antibacterial activity of selected Portuguese honeys. J Apic Res 44:119123.

16. Irish J, Carter DA, Shokoni T, Blair S (2006). Honey has an antifungal effect against Candida species. Med Mycol 44:289-291.

17. Izraili ZH (2014). Antimicrobial properties of honey. Am J Ther 21(4):304-323.

18. Kim D, Chun O, Kim Y, Moon H, Lee C (2003). Quantification of phenolics and their antioxidant capacity in fresh plums. J Agric Food Chem 51:6509-6515.

19. Louveaux J, Maurizio A, Vorwohl G (1978). Methods of Melissopalynology. Bee World 59:139-157.
20. Lusby PE, Coombes AL, Wilkinson JM (2005). Bactericidal activity of different honeys against pathogenic bacteria. Arch Med Res 36:464-467.

21. Moise A, Mărghitaş LA, Dezmirean D, Bobiş O (2013). Nutraceutical properties of Romanian heather honey. Nutr \& Food Sci 43(3):218 - 227.

22. Molan $P$ (1992). The antibacterial activity of honey. 1 . The nature of the antibacterial activity Bee World 73: 5-28.

23. Molan P (2001a) Why honey is effective as a medicine. Bee World 82:22-40.

24. Molan P (2001b) Potential of honey in the treatment of wounds and burns. Am J Clin Dermatol 2:13-19.

25. Oelschägel S (2011). Characterization of unifloral honeys using HS-SPME/GC-MS. Proc 42th APIMONDIA 2011, Buenos Aires Argentina.

26. Oelschägel S, Pieper L, Staufenbiel R, Gruner M, Zeippert L, Pieper B, Koelling-Speer I, Speer K (2012). Floral markers of cornflower (Centaurea cyanus) honey and its peroxide antibacterial activity for an alternative treatment of digital dermatitis. J Agric Food Chem 60:11811-11820.

27. Persanno Oddo L, Piro R (2004). Main European unifloral honeys descriptive sheets. Apidologie, 35:S38-S81.

28. Pires J, Estevinho ML, Feás X, Cantalapiedra J, Iglesias A (2009). Pollen spectrum, and physico-chemical attributes of heather (Erica sp.) honeys of north Portugal. J Sci Food Agric 89:1862-1870.

29. Singleton LV, Orthofer R, Lamuela-Raventos RM (1999). Analysis of total phenols and other oxidation substrates and antioxidants by means of Folin-Ciocalteu reagent. Method Enzymol 299:152-178.

30. Weston R (2000). The contribution of catalase and other natural products to the antibacterial activity of honey: A review. Food Chem 71:235-239.

31. Witczak M, Juszczak L, Gałkowska D (2011). NonNewtonian behaviour of heather honey. J Food Eng 104:532-537. 